(though here again I speak without first-hand knowledge) presumably not adapted for heavy points. Were heavy shafts used elsewhere in North America? What is the relation between bow strength and nature of arrow? I hope shortly to be able to contribute certain data regarding the heads of spear-thrower darts and arrow-heads from the Maya area.

A. V. KIDDER

Carnegie Institution of Washington

\title{
The Potawatomi as Alleged Mound-Builders ${ }^{146}$
}

In the article: Potawatomi, in the HandBook of THE AMERICAN Indians, Bull. 30, Pt. 2, BAE., initialed by J. M. and J. N. B. H., we read on Page 291, "Sir Daniel Wilson alludes to certain graves surmounted by small mounds, which the surveyors informed him were Potawatomi burial places. Other graves of the same character found in Iowa are also known to have been burial places of people of the same tribe." What Sir Daniel Wilson ${ }^{147}$ actually says is: "In several of the mounds of another group the surveyors noticed recent Indian graves, covered with slabs or stakes, in accordance with the usual method of Indian burial, and belonging to the Potawattomies; and Mr. Lapham adds: 'The larger and more conspicuous mounds are generally selected by the Indians for the burial of their dead.' "Lapham's Antiquities of Wisconsin ${ }^{148}$ is referred to; I do not know the precise passage, but on Page 59 will be found, "One of the oblong elevations was entirely covered with graves recently made by them"; Menomini and Winnebago are meant. That is to say, historic Indians used prehistoric mounds as burial places.

Truman Michelson

Bureau of American Ethnology

Washington, D. C.

\section{A Note on South American Parallels to Maya and Aztec Traits}

In his stimulating Observations on the Present Status and Problems of Middle American Archaeology ${ }^{149}$ Dr. J. Alden Mason indicates the South American relations suggested by Lacandon material culture. Possibly the affinities extend to other phases of native life.

According to Soustelle, ${ }^{150}$ these primitive Maya retain patrilineal totemism, as discovered by Tozzer some thirty years ago, but Soustelle's totemic groups are ranged in moieties named karsiya and kobo, and among the northwestern Lacandon he even reports an approximation to exogamy (contrary to Tozzer's observations):

${ }^{146}$ Printed by courtesy of the Smithsonian Institution.

147 Prehistoric Man, Vol. 1, p. 389; Cambridge and London, 1862.

${ }^{148}$ Smithsonian Contributions to Knowledge, Vol. 7, 1855.

${ }^{149}$ This series, Vol. 3, p. 306, 1938.

150 Jacques Soustelle, Le totémisme des Lacandones, in Maya Research, Vol. 2:325-344, 1935. 